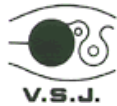

\title{
共鳴管からの放射音に及ぼす水没管長さの影響*
}

\author{
中園与一 ${ }^{1)}$, 大内可人 ${ }^{2)}$

\section{Effects of Pipe Length Immersed under Water on the Tone Radiated from the Resonance Pipe}

\begin{abstract}
Yoichi NAKAZONO and Yoshito OHUCHI
ABSTRACT

The purpose of the present research is to study the effect of a pipe length immersed under water on the tone generated from a resonated pipe caused by the impact sound of water drops on the water surface. Experiments have been carried out through the simultaneous measurement of both the generated sound and the formation of air bubbles. A water jet spouted instantaneously from the nozzle changes into many water droplets within a distance of about $20 \mathrm{~cm}$ from the nozzle exit. The dominated tone radiated from the exit of the resonated pipe is produced by the vibration of the air-bubbles and by the resonance of air-column in the pipe. If a pipe length is immersed deeper under water, the column of air-bubble is made longer and its vibration is generated later. Moreover, the pipe length immersed under water shifts the dominant frequency component of the sound source based on the bubble vibration to the lower frequency.
\end{abstract}

Keywords : Resonance, Water-droplet, Air-bubble, Pipe, Generation mechanism

\section{1. はじめに}

水の楽器は水面上部に共鳴管を，また水面下に短い管を 有す. 共鳴管の上部に設けたノズルから噴出された水ジェ ットは水面に多くの水滴となって衝突する.この衝突が音 源となって共鳴管による共鳴音が発生して共鳴管から音 が放射される 1 , 2).

これまで, 水滴が水面に衝突する際の音の発生機構は, 水琴窟と雨音の研究を中心にしてなされてきた $\left.{ }^{3)}-12\right)$. 水 の楽器による音源の発生機構はこれらと大きく変化しな いが，一部の管が水面下に水没して，気泡の形成を制御す るため, 形成された気泡の形も異なると思われる. それ故 発生音も変化すると考えられる. また放射される音も共鳴 管により基音だけでなく, 種々の倍音が放射される. 水の 楽器の水没長さを決定する上で, これらの研究は重要であ る.

そこで, 本研究では水の楽器設計の基礎資料を得るため に, 水没管長さが放射音によ゙のように影響するか研究した.

\section{2. 実験装置および方法}

Fig. 1 に実験装置の概略図を示す 13). ノズルから上部に 直径 $120 \mathrm{~mm}$ ，長さ $2000 \mathrm{~mm}$ の筒状タンクが設置され，

* 原稿受付 2009 年 6 月 12 日

1) 正会員 東海大学 産業工学部（广862-8652 熊本市渡鹿 9-1-1, E- mail : ynakazon@ktmail.tokai-u.jp)

2) 非会員 東海大学 産業工学部
このタンクの水位はノズルから噴出するジェットの噴出 速度を変えるために，変化できるようになっている．実験 は電磁弁の開閉時間をコンピュータ制御して水の噴出時 間を変えた。なお，通常の音符の長さの時間に近づけるた め，電磁弁開放時間は $100 \mathrm{~ms}$ とした．使用したノズルは 主に内径 $2 \mathrm{~mm}$, 長さ $20 \mathrm{~mm}$ である.ノズルから噴出した 水はノズル出口から $700 \mathrm{~mm}$ 下にある $350 \mathrm{~mm}$ 立方体の水 槽の水面に衝突する.この水槽からオーバーフローした水 は水面からこぼれるようになっているので, ノズルと水槽 水面の間の距離は一定に保たれている. 共鳴管は内径 $30 \mathrm{~mm}$, 肉厚 $2 \mathrm{~mm}$ のアクリル製である。共鳴部長さ $L t$ は $0,100,200,300,400 \mathrm{~mm}$ の 5 種類, 水槽内に沈む 管の水没長さ $L_{W}$ は $0,20,50,100,200 \mathrm{~mm}$ の 5 種類 である. 水圧 $H$ は $250 \mathrm{~mm}(2.45 \mathrm{kPa}), 500 \mathrm{~mm}(4.9 \mathrm{kPa})$, $1000 \mathrm{~mm}(9.8 \mathrm{kPa}), 2000 \mathrm{~mm}(19.6 \mathrm{kPa})$ である.

マイクロホンは共鳴管上端部の管中心から $100 \mathrm{~mm}$, $45^{\circ}$ の位置に固定した。騒音計の $\mathrm{C}$ 特性にて計測した音 は電磁弁が開放した瞬間からデータレコーダに取り込む ようにした. 水面に水滴が落下した瞬間の音は気泡を同時 撮影した高速度ビデオカメラによる可視化と対応付けて 判定した. また時系列音をみたとき, 落下した瞬時後の音 は，瞬前(音の発生無し)と僅かに波形が異なるので，水面 に水滴が落下後の音は時系列音からも判定が可能であっ た. データレコーダに取り込んだデータはコンピュータに て FFT 解析した. コンデンサマイクロホンによる計測と 同時に水中音も水中マイクロホンで計測した. 両計測のサ 
ンプリング周波数は $50 \mathrm{kHz}$ である. なお， $\mathrm{FFT}$ アナライ ザーを用いた周波数分析も行なった. 水面に落下する水滴 の形状や水面下に落下後の気泡の形状は 2000 コマ/s と 400 コマ/s のビデオカメラを用いて撮影した.

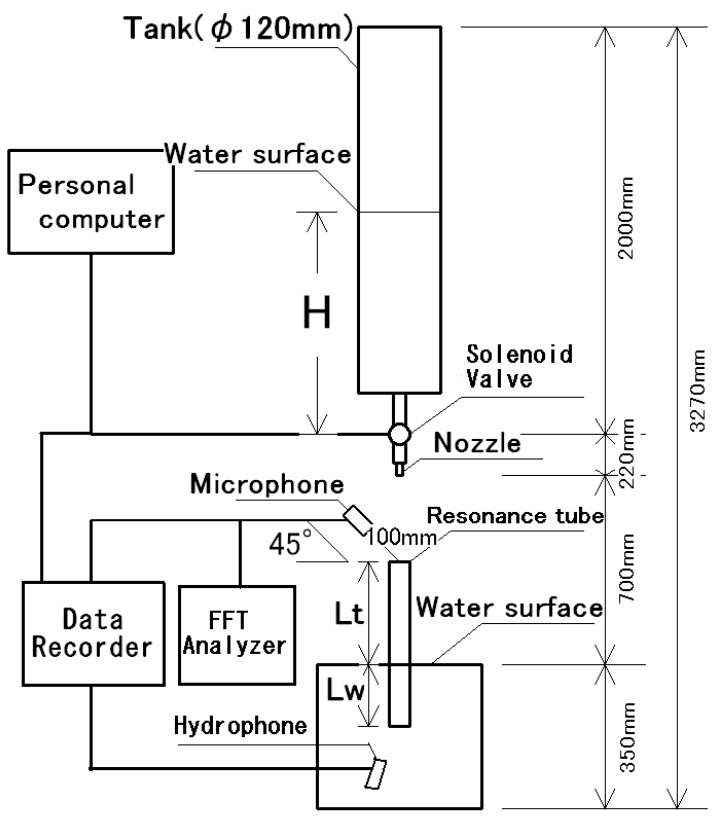

Fig. 1 Experimental apparatus.

\section{3. 水滴の速度}

ノズルから噴出したジェットは数珠玉状の膨らみとく びれを形成し，この膨らみはジェットの落下距離 $X$ とと もに次第に大きくなって, やがてジェットはばらばらの水 滴に分裂する. Fig. 2 にノズルからジェット先端部距離 $X$ とその場所における水滴の速度 $V_{X}$ の関係図を筒状のタン クの水位 $H$ を変えて, 即ち水圧を変化して示寸. 図中 $H$ の後の数字は水位 $(\mathrm{m})$ である.

水滴の形成される位置は圧力とともにノズルから離れ るが，ノズル出口から $200 \mathrm{~mm}$ 以内に収まる. また涙形の 主水滴も落下途中で球形に変化して, ほぼ球形で水面に衝 突する ${ }^{13)}$ ．水滴の速度 $V_{\boldsymbol{X}}$ は，次式で示すように，ポテン シャルエネルギーと運動エネルギーの関係から, 水圧と落 下距離（ノズル先端部から主水滴までの距離）の和のルー トで求まる.

$$
V x=\sqrt{2 g(0.2 H+x))}
$$

但し， $H$ は円筒水圧タンクの水面の高さ， $X$ はノズルとジ エット先端部の位置（最初の水滴）の間の距離である.

各位置 $X$ における速度は, 通常 $\rho g(H+X)$ の根の外に係 数を設けるのが一般的であるが 14)，この場合では実験と の一致が見られなかった。それ故ここでは実験結果と対比
して, $\rho g H に 0.2$ の係数を乗じた.

連続的に水面に落下寸る多くの水滴の現象を観察する と, それらの間隔が均一な場合もあれば，そうでない場合 もある.これはジェットから水滴への各水滴の分裂時間と 各水滴の落下速度が異なるためで, そのため水滴の間隔も 一定でない. 本実験で設定した内径 $2 \mathrm{~mm}$ のノズルから落 下した水滴の水面位置 $700 \mathrm{~mm}$ (水面一の水滴衝突位置)で は，最初に落下した主水滴の直径は $5.5 \sim 7.5 \mathrm{~mm}$, 第 2 滴 目以後の水滴直径は $3 \sim 4.5 \mathrm{~mm}$ の範囲であった. 但し水 滴の直径は落下方向の水滴の直径とそれに直角な方向の 水滴直径の平均(水滴の縦横直径の平均)によって定義され る. 最初の主水滴が落下寸ると, 水面のところでクレータ が形成される. その後次々と水滴が落下して, クレータ直 下に気泡が形成され, やがて気泡がクレータから切り離さ れて新たな気泡が形成される。このときに形成された気泡 が発生音に関係する。

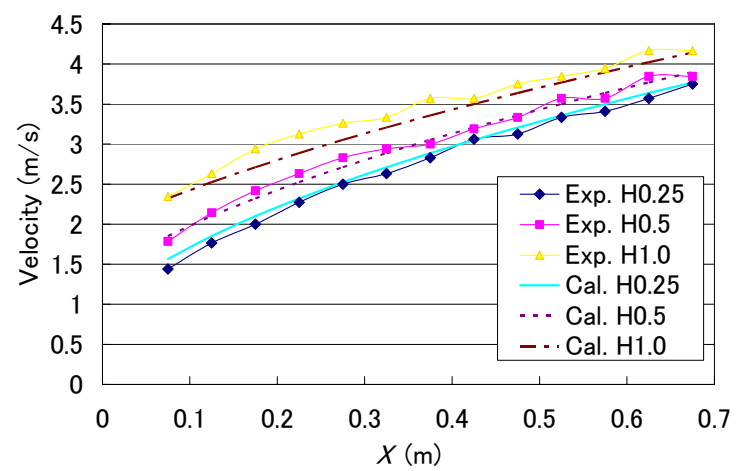

Fig. 2 Speed of water drop-let.

\section{4. 共鳴管がない場合 $(L t=0)$ の発生音}

\section{1 音源}

Fig. 3 に $(L t, L \mathrm{w})=(0,0), 9.8 \mathrm{kPa}(H=1000 \mathrm{~mm})$ でのコ ンデンサマイクと水中マイクによる時系列音を示す.この 図には気泡の形状写真も示寸. 図から, 水中音と空気中で の音の波形は強度の違いはあるが全体的に類似している ことがわかる. 水滴が水面に衝突してから $48 \mathrm{~ms}$ 後に大き な振幅が生じて, 時間が経過すると共に, 振幅は徐々に減 衰することがわかる.また，この約 $50 \mathrm{~ms}$ は気泡写真との 対応から,クレータ下部に形成された気泡が切り離された 時刻であることがわかる. 次に同時刻における空気中と水 中での発生音の音圧スペクトルをFig. 4 に示す.この Fig. 4 から空気中, 水中共に $520 \mathrm{~Hz}$ で大きな音が発生し ていることがわかる.またクレータ下部に形成された気泡 が切り離されたときにおける気泡の縦横の平均直径は Fig. 3 から約 $12 \mathrm{~mm}$ である. そこで, Minnaert31 泡の振動周波数の次式から 


$$
f=\frac{1}{\pi d_{a}} \sqrt{\frac{3 \kappa p}{\rho}}
$$

気泡振動周波数を求めると， $547 \mathrm{~Hz}$ である。このことか ら，実験值は計算值とほぼ一致する。但し， $d_{a}$ は気泡の 直径(気泡の縦横における長さの平均值として定義)， $\kappa$ は 気泡内部の空気の比熱比, $\rho$ は水の密度, $p$ は大気圧であ る. Fig. 5 に可視化写真から得られた気泡径と水圧の関係 を示す.気泡径は 20 回水を落下したときの平均值である. 圧力が高くなると気泡径にバラツキがあり， $H=2000 \mathrm{~mm}$ の場合気泡直径平均值の $\pm 0.4 \mathrm{~mm}$ のバラツキがみられた. $H=1000 \mathrm{~mm}$ 以下になると, $\pm 0.2 \mathrm{~mm}$ の範囲内でそれほど 大きなバラツキはみられなかった. Fig. 5 には実験結果か ら得られた平均気泡径 $d a(\mathrm{~mm})$ と水圧 $H(\mathrm{~mm})$ との下記の 実験式も示寸.

$$
d_{a}=0.002 H+9.878
$$

水圧を変化して水を落下したときのピーク音圧の周波 数と水圧の関係を Fig. 6 に示寸. 同図には, 式(2)に式(3) を代入して計算した気泡振動周波数の近似曲線も示寸. 図 から, 圧力が大きくなると, 気泡振動周波数は低くなるこ とがわかる. 以上のように, 水ジェットの水面への落下に よる発生音は圧力を変化しても気泡振動が主音源である ことがわかる。

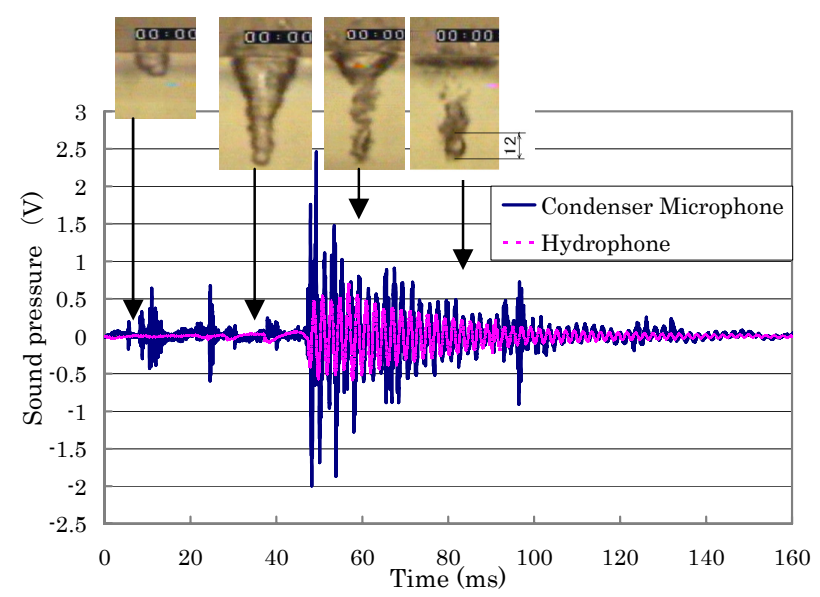

Fig. 3 Sound pressure with the passage of time, $(L t, L W)=(0 \mathrm{~mm}, 0 \mathrm{~mm}), H=1000 \mathrm{~mm}$.

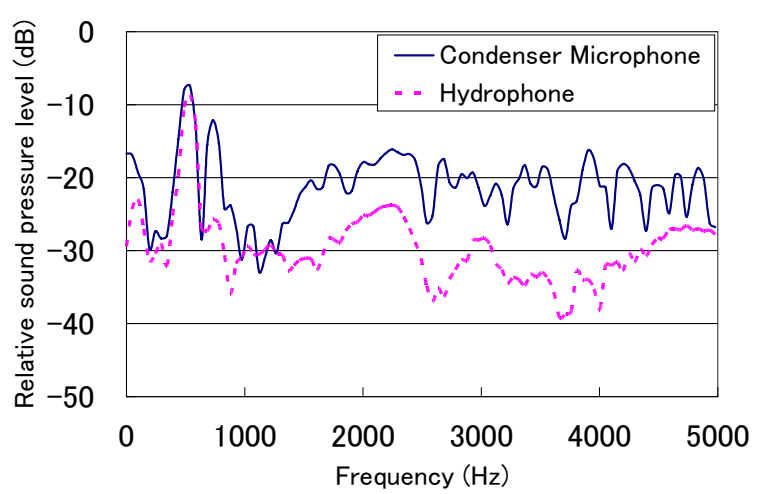

Fig. 4 Power spectra of relative sound pressure at time from 65 to $85 \mathrm{~ms}$, $(L t, L w)=(0 \mathrm{~mm}, 0 \mathrm{~mm}), H=1000 \mathrm{~mm}$.

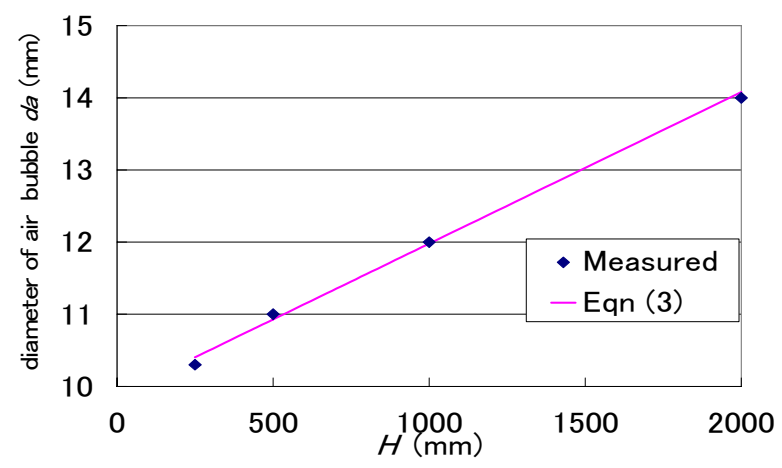

Fig. 5 Diameter of air bubble $d a$ vs. water pressure $H$.

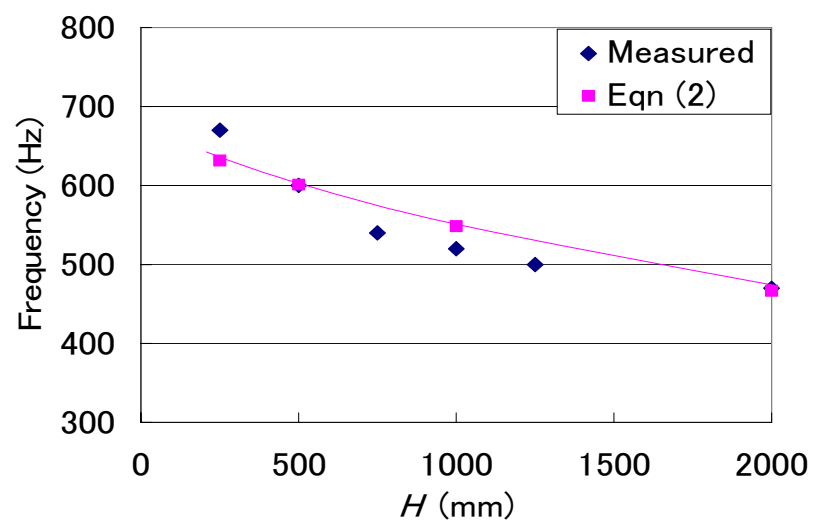

Fig. 6 Frequency of generation sound by air-bubble with water pressure, $(L t, L w)=(0 \mathrm{~mm}, 0 \mathrm{~mm})$.

\section{2 水没長さ $L w$ の影響}

Fig. 7 に $L t=0 \mathrm{~mm}$ で, $L W=20,100 \mathrm{~mm}$ の場合におけ る空気中の音圧スペクトログラムを示す．実験は水圧 $1000 \mathrm{~mm}$ で行なわれた. 図には気泡の可視化写真も示寸. 可視化写真でみられる一定な黒い横棒は水没管を挟んで いる器具の一部で, 本論とは無関係である. 
$L_{W}=20 \mathrm{~mm}$ では約 $500 \mathrm{~Hz}$ だけでなく, $1 \mathrm{kHz}$ 及び $3 \mathrm{kHz}$ 付近に大きな音圧が見られるが，この高周波数音は水没長 さが長くなると, 見られない. 気泡の大きさ（縦横平均直 径 $13 \mathrm{~mm}$ ）から判断する限りでは $500 \mathrm{~Hz}$ が気泡振動によ る音と推測される. $L_{W}=100 \mathrm{~mm}$ では約 $350 \mathrm{~Hz}$ に気泡振 動による大きな音が見られる.また電気ノイズと見られる 低周波数音も見られるが本論では対象外である. 次に Fig. 7 から, $L_{W}=20 \mathrm{~mm}$ の場合, 気泡振動の発生は $45 \mathrm{~ms}$ であるのに対して， $L_{W}=100 \mathrm{~mm}$ の場合， $55 \mathrm{~ms}$ と遅れて いる. また写真から， $L W$ を長くするとクレータ下部に形 成された数珠繋ぎの気泡が長くわかる. 本論では示してい ないが，さらに $L_{W}$ を長くしてもクレータ下部の気泡長 さの増長は見られず, また発生音の遅れも見られなかった. これらの事から, 気泡振動音の発生時刻はクレータ下部の 気泡長さに関係している. 実用的には, 基礎研究結果より 水没長さをむやみに長くすることは水没管部のタンクを 深くすることになるので, $100 \mathrm{~mm}$ 以下としている.

次に, 水没長さ $L W$ と気泡振動周波数との関係を調べた. Fig. 8 に水圧 $250 \mathrm{~mm}$ と $1000 \mathrm{~mm}$ について空気中に放射 した気泡音の周波数を $L_{W}$ の関数として示す. 図から $L_{W}$ が長くなると, 気泡振動による発生音の周波数は低くなる. しかし $L_{W}$ が $100 \mathrm{~mm}$ 以上になると, 気泡音の周波数はそ れ程低下しない. また水圧が大きくなると，Fig. 6 で示し たように, 気泡振動による発生音の周波数はさらに低くな る.

以上の気泡の可視化と発生音の関係から, 下記のことが 考えられる. 水没管が無い場合, 最初に落下した水滴で形 成された水面下部のクレータは, 落下した水滴の運動エネ ルギーにより決まり, この半径は実験によると, $H$ $=1000 \mathrm{~mm}$ の場合 $18 \mathrm{~mm}$ であった. 即ち, 水没管の半径 は $15 \mathrm{~mm}$ であるので，水没管を設けると，この水面下部 のクレータは変形する. 管を設けることにより, 水滴の陥 入を妨げる水面の動きが弱くなる. 次々に形成される気泡 は，管により横方向への広がりが抑えられ、慣性により気 泡は下方向に次々に形成されていく. $20 \mathrm{~mm}$ 管のように管 が短い場合, 管下からはみ出た気泡は管の横方向にも働く ので，管が無い場合と同様に，気泡は横方向に広がる性質 を持つ. それ故, 気泡群の影響はあるにせよ, 単一の気泡 に近い振動周波数で振動する. 管が長くなると気泡群はさ らに下方向に長くなり，振動周波数も低くなる．このこと

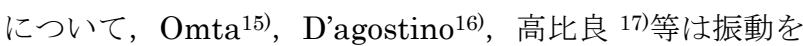
支配する物理が, 有限のボイド率をもつ気泡群の共振に変 化し, それゆえ気泡群の固有振動周波数が, 単一気泡に比 べて低くなると，説明している．100mm 程度の水没管長 さになると, 気泡群は水面から $65 \mathrm{~mm}$ ないし $70 \mathrm{~mm}$ 程度 まで伸び，共振周波数も大体一定になってくる．そのこと により $200 \mathrm{~mm}$ に管を長くしたとしても，共振周波数は $100 \mathrm{~mm}$ の場合と同程度となる. 水圧 $H$ が強くなると, 気
泡は大きくなり，また水深方向への慣性が大きいので気泡 長さも長くなる. それ故, 共振周波数も下がる.

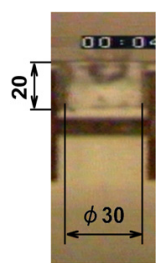

$5 \mathrm{~ms}$

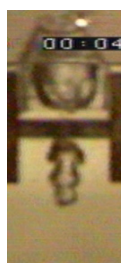

45

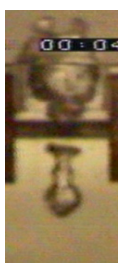

55

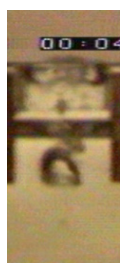

105

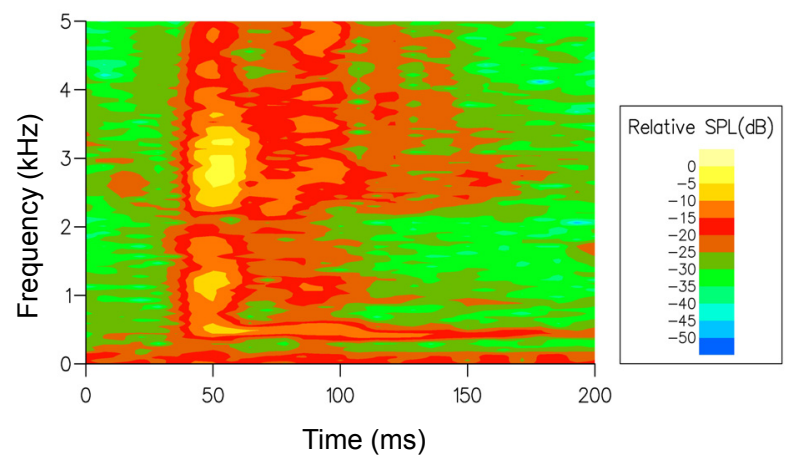

(a) $L_{W}=20 \mathrm{~mm}$

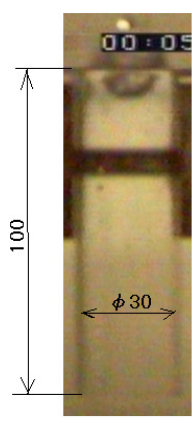

$5 \mathrm{~ms}$

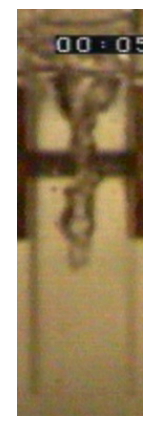

45

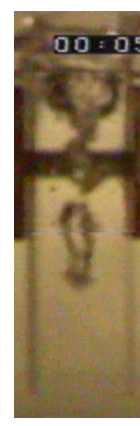

55

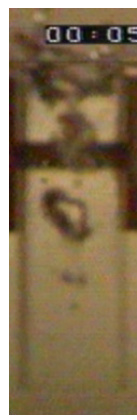

80

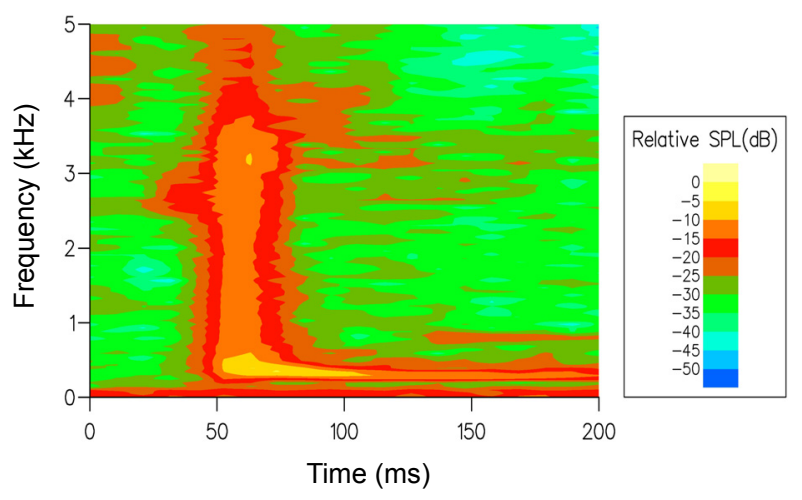

(b) $L_{W}=100 \mathrm{~mm}$

Fig. 7 Sound spectrogram radiated from resonance pipe for $L t=0 \mathrm{~mm}, H=1000 \mathrm{~mm}$. 


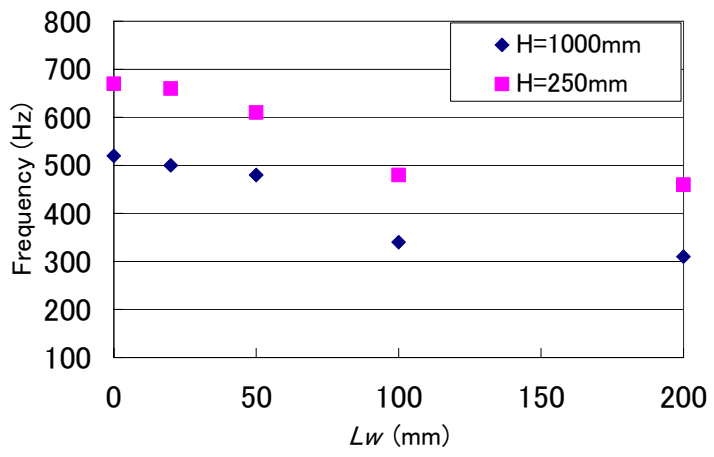

Fig. 8 Frequency of air-bubble vs. pipe depth in the water $L w, L t=0 \mathrm{~mm}$.

\section{5. 共鳴管 $L t$ を有す場合の発生音}

Fig. 9 に $\left(L t, L_{W}\right)=(200,20)$ での音圧の時間変化を示す. 縦軸は電圧 $(1$ 目盛り：1V) で示している. 水滴が落下し て $6 \mathrm{~ms}$ 後に約 $2.5 \mathrm{~ms}$ 周期の音が発生している。こ の周期は一端閉口他端開口の共鳴管長さの共鳴音 (基音約 $400 \mathrm{~Hz}$ ）に相当する. 図から $L t=0$ と異なり，水滴が落下 した瞬間後に共鳴管長さによる共鳴音が発生している。こ の理由は, 水滴が水面に衝突した瞬閒から気泡振動が発生 するまでの微弱強度音源が, 共鳴管に影響したものと思わ れる. $45 \mathrm{~ms}$ 頃クレータから気泡が切り離されて(Fig. 9 の 写真 (c) 参照), 気泡振動が生じ，倍音を含む共鳴管による 共鳴音が発生する．この共鳴音は $90 \mathrm{~ms}$ 程度から，時間経 過とともに徐々に減衰し，160ms からは不明瞭である.

$L W$ を $100 \mathrm{~mm}$ に長くしたときの結果をFig. 10 に示す. $L W$ を長くすると, 主水滴が水面に衝突した初期での共鳴 管による共鳴音は $L W=20$ に比べて小さくなることがわか る. この音の強弱は水没長さに依存していると思われる. また水没長さが長くなると, 水没長さが短い場合に比べて, 気泡振動は遅れて発生する。 $55 \mathrm{~ms}$ 付近で気泡が切れて (Fig. 10 の写真 (d)参照), 気泡振動が生じ, 約 $400 \mathrm{~Hz}$ の 正弦波の共鳴音が発生している。更に共鳴音は約 $230 \mathrm{~ms}$ まで持続している，即ち，水没長さを長くすると，共鳴管 の共鳴を長時間維持できる。また Fig. 7 で述べたように， 共鳴管を設けた場合も水没長さ $L W$ が長くなると, 気泡振 動音は遅れることがわかる。

\section{Lwが平均音圧スペクトルに及ぼす影響}

\section{1 共鳴管がない場合の音圧スペクトル}

Fig. 11 に水没長さ $L_{W}$ による音圧スペクトルの変化を 示す．縦軸の SPL は音圧レベル (Sound pressure level) で ある. 実験結果はジェットを水面に 20 回落下して発生し たそれぞれの音圧のスペクトルを加算平均したものであ る。また電磁弁に作用する水圧は $9.8 \mathrm{kPa}(H=1000 \mathrm{~mm})$ である．図から水没長さ $L W$ が長くなると，前章で説明し
たように, 主要周波数成分が低周波数側にシフトすること がわかる。

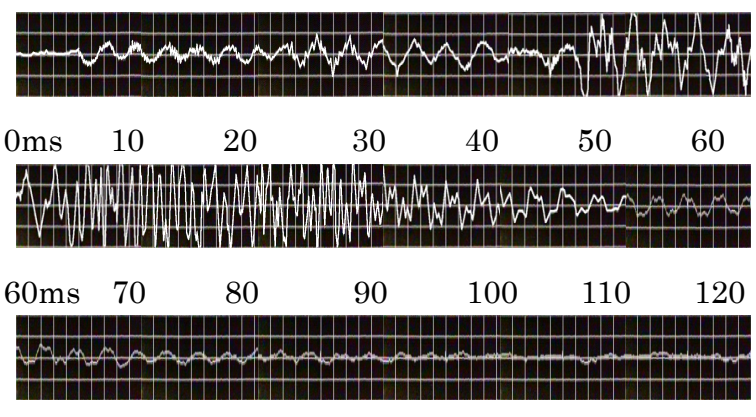

$\begin{array}{lllllll}120 \mathrm{~ms} & 130 & 140 & 150 & 160 & 170 & 180\end{array}$

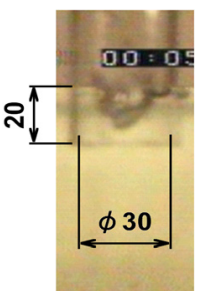

(a) $5 \mathrm{~ms}$

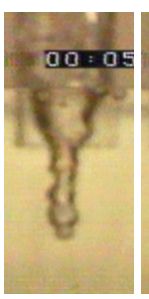

(b) 35

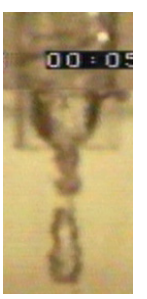

(c) 45

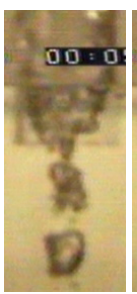

(d) 75

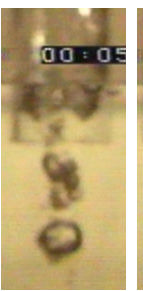

(e) 90

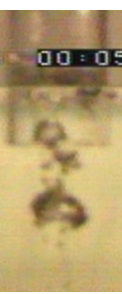

(f) 130
Fig. 9 Sound pressure with the passage of time, $\left(L t, L_{W}\right)=(200 \mathrm{~mm}, 20 \mathrm{~mm})$.

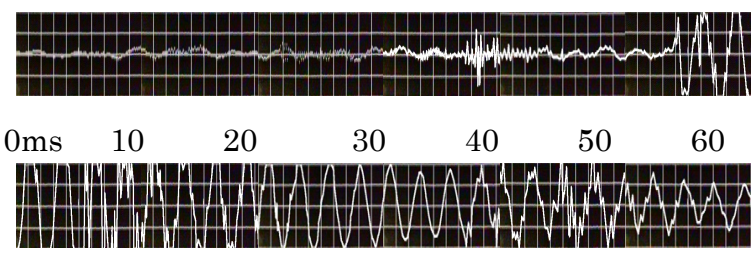

$\begin{array}{lllllll}60 \mathrm{~ms} & 70 & 80 & 90 & 100 & 110 & 120\end{array}$

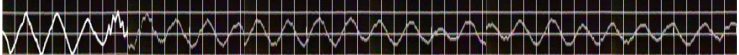

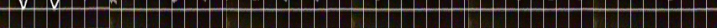

$\begin{array}{lllllll}120 \mathrm{~ms} & 130 & 140 & 150 & 160 & 170 & 180\end{array}$

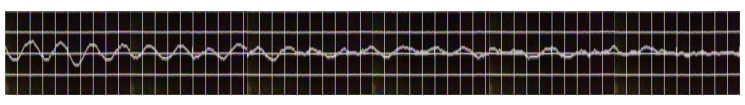
180ms $190 \quad 200 \quad 210 \quad 220 \quad 230 \quad 240$

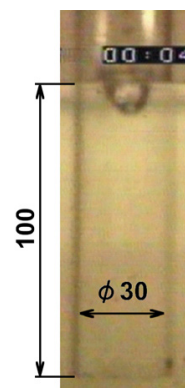

(a) $5 \mathrm{~ms}$

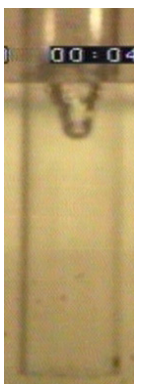

(b) 15

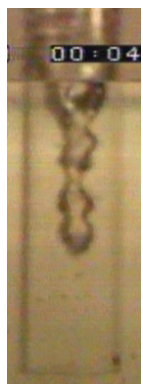

(c) 45

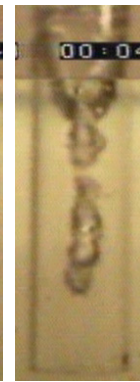

(d) 55

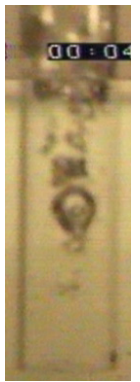

(e) 105

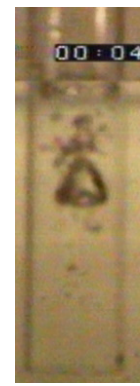

(f) 135
Fig. 10 Sound pressure with the passage of time, $(L t, L W)=(200 \mathrm{~mm}, 100 \mathrm{~mm})$. 


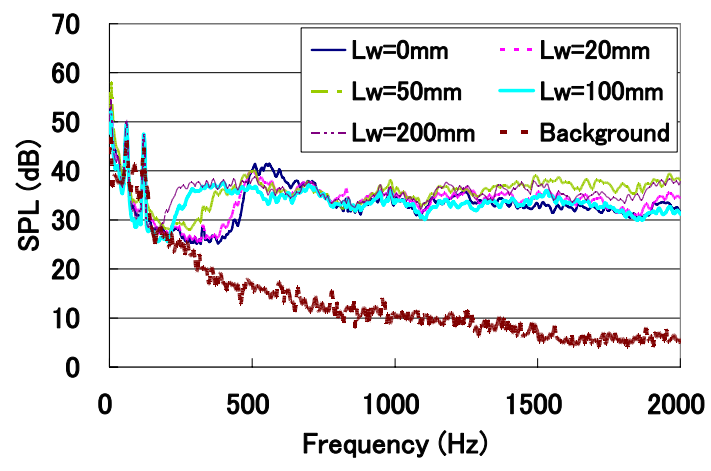

Fig. 11 Effect of pipe depth $L_{W}$ on the sound pressure spectra, $L t=0 \mathrm{~mm}$.

\section{2 共鳴管からの放射音}

Fig. 12 に $L t=200 \mathrm{~mm}$ の共鳴管, $L_{W}=20,100 \mathrm{~mm}$ の 水没管による放射音の音圧スペクトルを示す。実験結果 (Exp)はFig. 11 と同様にジェットを水面に 20 回落下した ときの音圧スペクトルの平均值である。図には計算值 (Cal) も示寸. 計算結果はFig. 11 に示した $L t=0 \mathrm{~mm}$ の音 圧スペクトルの発生音が音源となって, 次式の共鳴管に関 する気柱共鳴 2) の計算值がプラスされたものである。

$$
R L=-10 \log _{10}\left(\cos ^{2} k(l+\Delta l)\right)
$$

但し， $\Delta l=0.6 d / 2, k$ は波長定数， $l$ は水面から管の開 口端までの長さ (共鳴部長さ),$d$ は共鳴管の直径である. Fig. 12 の $L_{W}=20 \mathrm{~mm}$ と $100 \mathrm{~mm}$ に対する各計算值は, 実 験值と㛜密には一致しないが定性的には一致しており, 共 鳴管からの放射音の現象をよく説明できる. 具体的に述べ ると, 基音 (約 $400 \mathrm{~Hz}$ )の実験值では $L_{W}=100 \mathrm{~mm}$ の音圧 レベルが $L_{W}=20 \mathrm{~mm}$ より大きいが, 計算值も同様な現象 を示す.一方, 第 3 モード $(1200 \mathrm{~Hz})$ 及び第 5 モード（約 $2000 \mathrm{~Hz})$ の実験值を見ると, $L_{W}=100 \mathrm{~mm}$ の場合は $L_{W}$ $=20 \mathrm{~mm}$ に比ベピーク点が若干 $(60 \mathrm{~Hz}$ 程度）高周波側に シフトしている. すなわち $L_{W}$ を長くすると, 見かけ上 共鳴音全体が高周波数側に移動する.こうした現象は計算 值でも同様の結果が得られている.

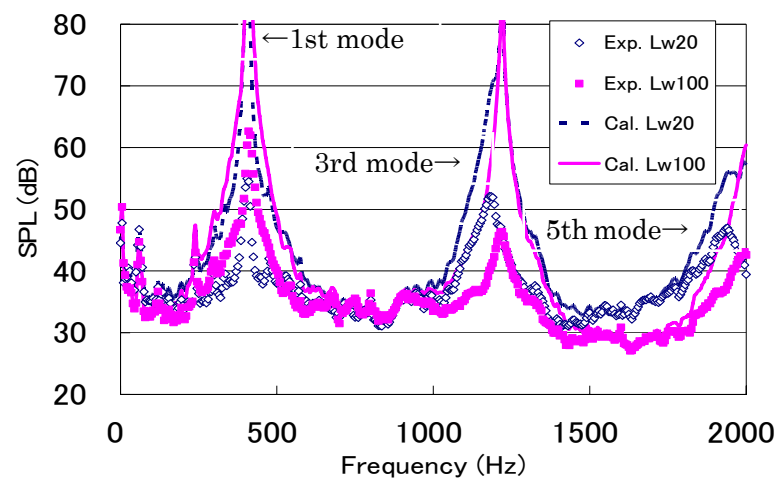

Fig. 12 Radiated sound from the resonance pipe, $L t=200 \mathrm{~mm}$.
このことから， $L t=0 \mathrm{~mm}$ での音圧スペクトルが共鳴管出 口からの放射音を決めることがわかる.また音源の音は気 泡振動に主に支配されるので, この気泡振動の音圧スペク トルが得られれば，共鳴管からの放射音も決まる。

\section{7. 結び}

水没長さが共鳴管からの放射音に及ぼす影響を可視化 と音響測定から研究した。 その結果次の事がわかった。

（1）共鳴管からの放射音は気泡振動による発生音が主音 源で, この音源と管の気柱共鳴モードの周波数によっ て決まる。

（2）水没長さを長くすることによって，クレータ下部に 形成される気泡が長くなり, そのことにより気泡振動 の発生が遅れる。

（3）音源の周波数は水没管がない場合，1個の気泡振動 が主音源であるが, 水没長さが長くなると気泡群の共 鳴周波数が支配的となり，それ故音源の主要周波数成 分は低周波数側にシフトされる.

本研究にご協力いただいた 2007 年度当時の院生 (現在, 三島光産（株）勤務）の大竹一慶氏と, 学部生（現在，南 西機械（株）勤務）中重友和氏に感謝の意を表します.

\section{参 考 文 献}

1) 中園与一: 楽器, 特許第 3460670, (2003).

2) 中園与一・高山明久: 雨垂れを利用した楽器の開発, 産業技術教育 学会誌, 45 卷 4 号 (2003) pp.183-189.

3) Minnaert, M. : On musical air-bubbles and the sound of running water, Phil. Mag. Vol.16 (1933) pp.235-248.

4) Frantz, G.J. : Splashes as sources of sound in liquids, J. Acoust. Soc. Am., Vol.31 (1959) pp.1080-1096.

5) Pumphrey, H.C. \& Crum, L.A. : Free oscillations of near-surface bubbles as a source of the underwater noise of rain, J. Acoust. Soc. Am., Vol.87 No.1 (1990) pp.142-148.

6) Ogurz, H. N., Prosperetti A. \& Kolani A. R. : Air entrapment by a falling water mass, J. Fluid Mech. Vol.294 (1995) pp.181-207.

7）森康夫・水上雅人・武士保健：剛球または水滴の水面への落下及び 水流により発生する音の研究, 機械学会論文集 (B 編), 57 巻 487 号, (1987) pp.181-207.

8）岩瀬照雄 : 伝統の仕掛け音 (水琴窟の音を中心として), 騒音制御, 24 巻 3 号 (2000) pp.198-201.

9）冨田幸雄 : 伝統技芸「水琴窟の音発生原理と試作研究」, 産業技術教 育学会 H15 年度機械分科会研究発表要旨集, (2003) p.1.

10) Tomita, Y. Saito, T. \& Ganbara, S. : Surface breakup and air bubble formation by drop impact in the irregular entrainment region, J. Fluid Mech. Vol.588 (2007) pp.131-152.

11) Watanabe, Y. : Analytical study of acoustic mechanism of "Suikinkutsu", Japanese Journal of Applied Physics, Vol.43 No.9A (2004) pp.6429-6443.

12) Strasberg, M. : The pulsation frequency of nonspherical gas bubble in liquids, J. Acoust. Soc. Am., Vol.25 No.3 (1953) pp.536-537.

13）大竹一慶・中園与一・松本欣也 : 水没長さが水の楽器の音響特性に及 
ぼす影響, 産業技術教育学会九州支部論文集, 15 巻 (2007) pp.7-13. 14）中園与一 : 初めて学ぶ人の流体工学, 三恵社, (2003) p.117.

15) Omta, R. : Oscillations of a cloud of bubbles of small and not so small amplitude, J. Acoust. Soc. Am., Vol.82 No.3 (1987) pp.1018-1033.
16) D’agostino, L. \& Brennen, C. E. : Linearized dynamics of spherical bubble clouds, J. Fluid Mech. Vol.199 (1989) pp.155-176.

17）高比良裕之・赤松映明・藤川重雄 : 液体中での気泡群の力学（第 1 報, 理論解析), 日本機械学会論文集 (B 編), 58 巻 548 号 (1992) pp.1262-1282. 